\title{
Digital methods in researching Slovakia Hungarian regional dialects
}

\author{
Károly Presinszky* [D
}

Institute of Hungarian Language and Literature, Faculty of Central European Studies, Constantine the Philosopher University, Nitra/Nyitra, Slovakia

\section{ORIGINAL RESEARCH PAPER}

Received: August 15, 2020 • Accepted: September 29, 2020

Published online: February 16, 2021

(C) 2020 Akadémiai Kiadó, Budapest

\begin{abstract}
This study overviews the most recent digital methods used in Slovakia Hungarian dialectology. Slovakia Hungarian dialectology started out by using the most modern digital methods in 2010 at Nitra/Nyitra university, creating regional dialect databases, first for the Žitný ostrov/Csallóköz region and then for the whole Slovakia Hungarian dialect region. Recording and processing data has been carried out with the help of the Bihalbocs software developed by Domokos Vékás and Fruzsina Sára Vargha in Hungary. The present paper first provides an overview of digital methods in dialectology and its results for Hungarian dialects, and then summarizes the results of the Nitra/Nyitra team so far, illustrating the diversity of digitized dialectological data. It discusses the findings of publications reporting on the results of this research, including maps showing the geographical and social distribution of linguistic phenomena and acoustic phonetic analyses of data aligned with sound files. Important output of this research also includes recently published audiobooks of Slovakia Hungarian dialects. The paper outlines further avenues of research based on the most recent findings.
\end{abstract}

\section{KEYWORDS}

dialectology, Slovakia Hungarian regional dialects, dialect features, digital methods in dialectology, audiobooks

Dialectology is an empirical discipline. It handles large amounts of data in diverse ways, and this fact makes it not only possible to use modern digital tools but also necessary. Digital methods provide immense opportunities in storing, visually presenting, and processing dialect data. The first attempts to use them in Hungarian dialectology emerged in the 1990s, when, at Lajos Balogh's

\footnotetext{
${ }^{*}$ Corresponding author. E-mail: kpresinszky@ukf.sk
} 
initiation, the entry of the data from the atlas of Hungarian dialects (Deme and Imre, 1968) $(A$ magyar nyelvjárások atlasza, widely referred to as MNyA) into a database began (Balogh and Kiss, 1992). Domokos Vékás developed various technological tools for efficient digital recording and handling of dialect data in Hungary. He used methods developed in other countries and adapted them to Hungarian data, creating the Bihalbocs software (Vékás, 2007), which meets the needs of researchers studying dialects and processing regional dialect materials in the 21 st century. It is a special word processing, audio engineering, and map generating software that allows for specially coded regional dialect data to be recorded and organized in a database and then used in diverse ways by researchers (Bodó and Vargha, 2008). The advantage offered by digitized data and databases is that they can be integrated with other databases, are precise in recording of data, and connect transcriptions with audio files, allowing for various ways of subsequently analyzing the data. The Bihalbocs multimedia database software has been used in the past 15 years for the digitization and integration of dialect dictionaries and dialect atlases as well as the creation of audio dialect databases. Juhász (2014) provides an overview of the results of Hungarian digital dialectology. Bihalbocs is being further developed by Fruzsina Sára Vargha, who provides accounts of an increasing number of applications of digital technology in dialectology in her articles as well as her recent monograph on the dialectometric analysis of Hungarian regional dialects (Vargha, 2017).

The digital processing of Slovakia Hungarian regional dialect data has lagged somewhat behind similar work on Hungarian dialects in other countries neighboring Hungary, offset in the past 15 years by Anna Sándor's dialect atlas of the Nitra/Nyitra region (Sándor, 2004) and Lajos Cs. Nagy's dialect atlas of Podmedvedie/Medvesalja (Cs. Nagy, 2011). The most recent research in digital dialectology has been done at the Institute of Hungarian Language and Literature, Constantine the Philosopher University, in Nitra/Nyitra, where a group of dialectologists produced a comprehensive volume on Slovakia Hungarian regional dialects (Menyhárt et al., 2009).

In 2010, József Menyhárt and I (both of us natives of the Žitný ostrov/Csallóköz region) started research aimed at mapping out the features of the Žitný ostrov/Csallóköz regional dialect of Hungarian. Our original goal was the compilation of a comprehensive regional dialect atlas including all possible research sites, in order to gain an in-depth understanding of the Žitný ostrov/Csallóköz dialects and their changes. Detailed digital recording of data is required for this kind of analysis: the audio recordings collected at the research sites are stored in an organized fashion, allowing for the creation of audio text collections, maps, audio atlases, and other research output. We planned and carried out the processes of Žitný ostrov/Csallóköz regional dialect data collection with the help of the Bihalbocs software (first used in Slovakia by us) in helpful consultation with Domokos Vékás and Fruzsina Sára Vargha.

The material collected with a 280 question dialectology questionnaire and a 50 question sociolinguistic questionnaire in the Žitný ostrov/Csallóköz settlements constitutes the basis of our linguistic corpus. We worked with 10 speakers at each data collection site. We also collected recordings of texts and of minimal pairs for an acoustic phonetic investigation. The fieldwork was carried out with the assistance of Hungarian major students of the Faculty of Central European Studies, Constantine the Philosopher University, Nitra/Nyitra.

The originally planned dialect atlas of the Žitný ostrov/Csallóköz region is under compilation: data from 10 research sites (cf. Map 1 below) have been processed thus far, so currently we have almost 30 thousand pieces of data digitized.

The 10 research sites represent the entire Žitný ostrov/Csallóköz region, bordered by the Danube and the Little Danube. Four settlements - Kostolná Gala/Egyházgelle, Bodíky/Bodak, 


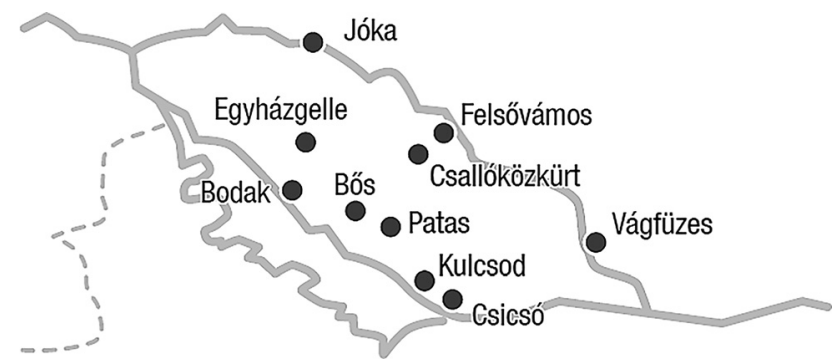

Map 1. Research sites of the Žitný ostrov/Csallóköz region processed so far (with the names of research sites given in Hungarian)

Ohrady/Csallóközkürt, and Horné Mýto/Felsővámos - belong to the northern part of Žitný ostrov/Csallóköz (Upper Žitný ostrov/Felső-Csallóköz), and four others - Gabčíkovo/Bős, Pataš/ Patas, Klúcovec/Kulcsod, and Číčov/Csicsó - to the southern part (Lower Žitný ostrov/AlsóCsallóköz). Vrbová nad Váhom/Vágfüzes in the Northern Danube subregion and Jelka/Jóka in the Matúšova zem/Mátyusföld subregion were included in the study as control sites.

\section{DIGITIZED DIALECT ATLAS: MAPS}

One of the goals of processing the language data is to create a digital dialect atlas which records regional dialect data in the code used by Hungarian dialectologists. An integrated database containing our data as well as that of other Hungarian dialectologists allows for a unified use and handling of all the data. Analysis is greatly aided by the formerly time consuming tasks (e.g. the plotting of the geographical distribution and frequency of use of sounds) being automatically done with the help of digital tools. Color coded pie charts can be generated to show the proportion of local variants in the whole. The only precondition is that data have to be entered into the system. The first level of coding is phonetic transcription which is detailed enough so no features of the originally pronounced forms are lost.

This technology appears in the papers that discuss some characteristic features of the Žitný ostrov/Csallóköz dialect, for instance, the sporadically occurring $\ddot{o}$-pronunciation, the use of assimilative unrounded $\dot{a}$ before $a$, or the use of assimilative $o$ after $a ́$ (Menyhárt, 2012; Menyhárt and Presinszky, 2013; Presinszky, 2012). As an illustration, I want to discuss some maps of vowel shortening in the Žitný ostrov/Csallóköz dialect based on an earlier paper (Presinszky, 2016a).

In that earlier paper I discussed the short vs. long pronunciation of high vowels in the responses of 100 speakers at the above mentioned 10 research sites, attempting to point out the geographical characteristics of this feature as affected by the social characteristics of the speakers, in 7 words (which was the total of the words included in the 280 question questionnaire for the investigation of this phenomenon). The high vowel under investigation occurs in the first, stressed syllable in each.

Map 2 provides the data on the total of the responses on the forms szive "his/her/its heart" and szivük "their heart". In the map, the darker color indicates the standard variant with the long vowel, whereas the lighter color indicates the regional variant with the short vowel. 


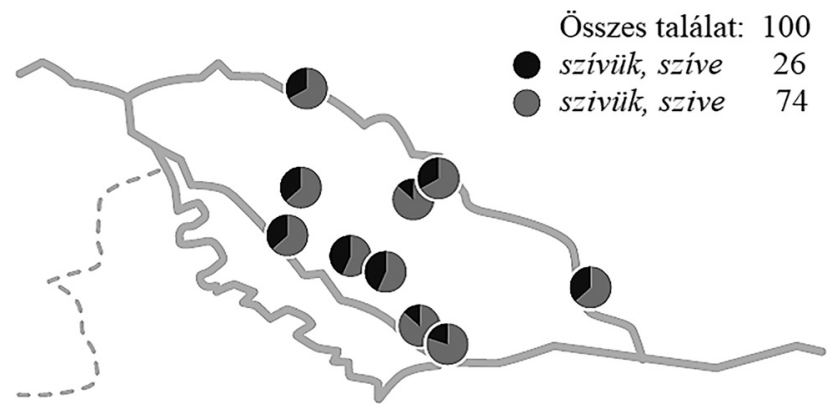

Map 2. The distribution of the variants of szivük and szive

The coloring in the pie charts indicates the distribution of standard vs. regional forms in each research site.

As we can see, almost three-quarters of the respondents gave the regional variant. The standard variant was also provided at every settlement, but by less than one-third of the respondents at every place. We can conclude that the regional variant is frequently used everywhere.

In addition to providing the totals for settlements, Bihalbocs can also show variation by age, education, and gender. In Map 3, responses by young (fiatal), middle-aged (középkorú), and older (idos) respondents are summarized.

The results in Map 3 show that the standard variant is more widespread among young people than among the middle aged, and that the regional variant predominated among the elderly. These data show clearly that the use of regional variants increased with age.

The Bihalbocs software also allows the researcher to indegrate data with other databases. Map 4 shows the above discussed data from the Žitný ostrov/Csallóköz dialect atlas, under preparation (Csallóköz nyelvatlasz "CsKA"), against corresponding data from the Hungarian dialect atlas (A magyar nyelvjárások atlasza, "MNyA").

Map 4 demonstrates that the regional, short vowel forms predominate in western, northeastern, and Transylvanian dialect regions, whereas the standard, long vowel forms do in the

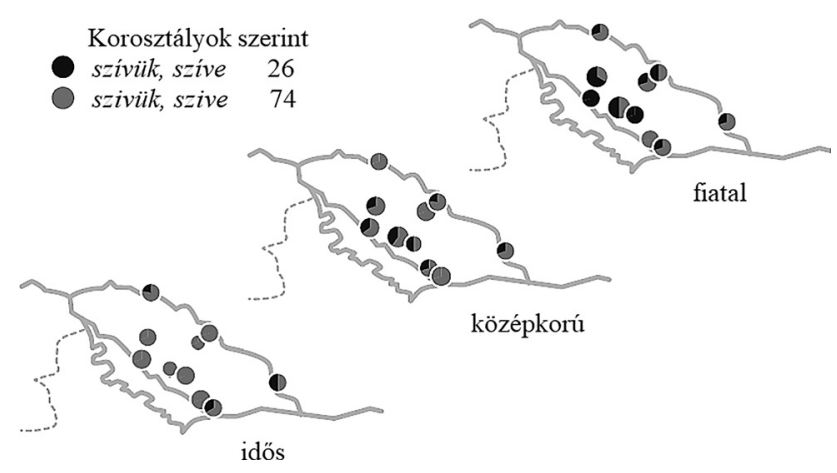

Map 3. The distribution of the variants of szivük and szive by age (young $=$ fiatal, middle-aged $=$ középkorú, and older $=$ idös) 


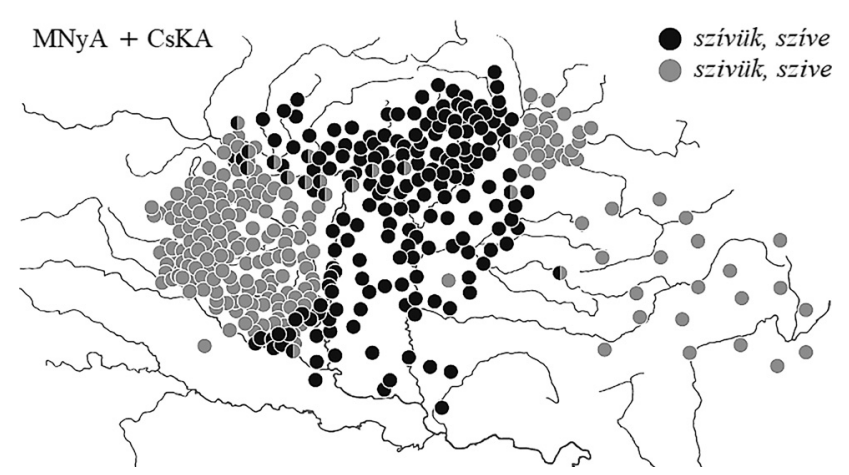

Map 4. The distribution of the variants of szivük and szive in MNyA and CsKA

central part of the language area. The places where both forms are used do not form a continuous area, and in the Slovakia Hungarian speaking region the standard variants predominate outside the Žitný ostrov/Csallóköz region, separated by a rather sharp boundary. In this feature, the Žitný ostrov/Csallóköz regional dialect shows a similarity with the Central Transdanubia/Little Hungarian Plain region.

\section{AUDIO DATA: ACOUSTIC PHONETIC ANALYSIS}

A definite advantage of the Bihalbocs software is that the transcribed forms can be aligned with the audio files showing their pronunciation, and this connection between the two is kept in the database as well, allowing for the possibility of generating audio illustrated dialect atlas pages and of using the data for acoustic phonetic analysis (Vargha, 2011). As an illustration of the latter, I briefly discuss some examples from an earlier paper (Presinszky, 2016b) in which I studied the phenomenon of unrounded $\stackrel{a}{a}$ pronunciation before $a$.

In the Žitný ostrov/Csallóköz and Malý Žitný ostrov/Szigetköz dialect group, the Hungarian low back rounded $<\mathrm{a}>$ vowel is often pronounced unrounded and lower (traditionally marked in transcription as $\dot{a}$ ) than in the standard when it precedes the long unrounded low mid vowel <á $>$ in a word, e.g. as mádár, kápál rather than madár "bird" and kapál "to hoe", respectively. This feature is phonologically conditioned and assimilative. According to the data of the Hungarian dialect atlas, MNyA, this feature was not general in Žitný ostrov/Csallóköz 60 years ago, however, the unrounded realizations of the vowel were as diverse then as they are now. If we examine the geographical distribution of this pronunciation today, we see that it occurs sporadically, not forming a continuous area. For instance, the realizations of the regional határ variant of határ "border" total about $10 \%$ of all responses, geographically found primarily in the northern and central research sites of the Žitný ostrov/Csallóköz region.

To analyze the realizations of the vowel in question, I have selected two forms, határ "border" and haza "homeland" from the questionnaire used in Žitný ostrov/Csallóköz and analyzed their formant values in one word responses provided by 100 respondents. In the Hungarian phonetics literature, the first and second formant values (the values that determine vowel quality) of the vowel $a$ are $200-300 \mathrm{~Hz}$ higher than those of the vowel $a$ (Gósy, 2004, p. 115). 
I hypothesized that the formant values of $a$ in határ (in the position where it is prone to assimilation in the dialect) will be higher than those of the $a$ in the first syllable of haza, regardless of whether the difference can be perceived by listeners or not. I also aimed to characterize in more detail the phonetic qualities of the Žitný ostrov/Csallóköz dialectal $\dot{a}$ sound with the help of the empirical data. For the analysis, I selected the recordings of the words határ and haza from every respondent's files and converted all of them into Praat to measure the formant values of the $a$ sounds. I entered the measured first and second formant values (a total of 864 of them) into an Excel sheet. I categorized the respondents into two groups: those in whose speech the $a$ in határ was audibly different vs. those in whose it was not. The analysis has shown that, except for two speakers, all respondents who produced unrounded $\dot{a}$ variants did so audibly. The data show that the unrounded $\dot{a}$ pronunciation produced unanimously increased F1 values: while in the case of the standard rounded $a$ they were between 500 and $700 \mathrm{~Hz}$, in the case of $\dot{a}$ they were between 700 and $800 \mathrm{~Hz}$. F2 values did not demonstrate a clear difference, falling between 1,000 and 1,500 Hz.

A further analysis of the data was focused on comparing the F1 and F2 values of the pronunciations of the two words, határ and haza, in the speech of the respondents. It has revealed that the forms where an audible difference was produced by a speaker, the values of both F1 and F2 for the sound $a$ were indeed higher in határ than in haza, with F1 being between 700 and $800 \mathrm{~Hz}$ in the former and $450-650 \mathrm{~Hz}$ in the latter.

The acoustic phonetic measurements of the Žitný ostrov/Csallóköz data have empirically demonstrated the unrounded quality of the $a$ sound in syllables preceding $a$ as well as a more fronted pronunciation than that of the standard $a$.

\section{REGIONAL DIALECTAL TEXTS: AUDIOBOOKS}

During the data collection in Žitný ostrov/Csallóköz, regional dialectal speech of 10-15 minutes was also recorded with every respondent with the aim of observing continuous speech in a situation where speakers were not forced to radically change their speech since they were asked to talk about their favorite topics. Most respondents talked about their childhood, their family, their work, their hobbies, or folk customs. Such recordings can be organized, with the help of Bihalbocs, into audiobooks that reflect not only the characteristics of the regional dialect but also provide an insight into the diversity and ethnographic character of people's lives in the given region. The audiobook produced is effectively a multimedia collection of texts in transcribed phonetic as well as audio form. The first of such audiobooks were produced, starting in 2005, by the Geolinguistics Team at Eötvös Loránd University, Budapest, processing Hajdú and Kázmér's 1974 Hungarian collection of dialect texts, the result of which has been a series of 9 audiobooks published on CDs as well as in HTML format on the Internet.

I started processing the Žitný ostrov/Csallóköz materials in 2017 with the aim of producing similar audiobooks. The audio files were processed in Bihalbocs in BXT format on a Macintosh computer, aligning the transcribed text files with the WAV audio files. Through the time markers in the text, the text files can be connected with the audio files with millisecond precision. Aligning starts from the audio file, the time markers mark the pauses in the speech as well as the beginning and end of an utterance. With the help of the time markers, the dialect data and any part of the text can be listened to at any time, without having to look up the original file and search it for the part one wants to check. The original audio form is available 
even after the text is arranged in the database, and the original transcription can be modified and corrected (Vargha, 2007).

This is the technique with which the Slovakia Hungarian dialect audiobook was made. It now has three volumes: the first using the Žitný ostrov/Csallóköz materials, and the other two using Slovakia Hungarian regional dialects from the other two dialect regions. These audiobooks are freely available at the website of the Faculty of Central European Studies, Constantine the Philosopher University, Nitra/Nyitra. ${ }^{1}$

The Slovakia Hungarian regional dialects are natural continuations of the Hungary Hungarian dialect regions. The Hungarian language area in the Carpathian Basin is divided into ten dialect regions by Kiss (2001, p. 264). Three of them extend into the territory of present-day Slovakia: (i) the Central Transdanubia and Little Hungarian Plain dialect (or Transdanubian dialect, by its earlier designation), (ii) the Palóc dialect, and (iii) the Northeastern dialect. The characteristics of these three dialect regions are described in the three volumes of the Slovakia Hungarian regional dialect audiobooks. Volume 1 contains texts primarily from the Žitný ostrov/Csallóköz region, from the following research sites: Gabčíkovo/Bős, Ohrady/Csallóközkürt, Ižop/Izsap, Klúcovec/ Kulcsod, Bodíky/Nagybodak, Topoľníky/Nyárasd, Vrbová nad Váhom/Vágfüzes, Trhová Hradská/Vásárút, and Žihárec/Zsigárd. Volume 2 contains texts from the very divided Palóc dialect from the following sites: Jelšovce/Nyitraegerszeg, Velké Chyndice/Nagyhind (Northwestern Palóc dialect group), Tekovské Lužany/Nagysalló, Šarkan/Sárkányfalva (Western Palóc dialect group), Ipeľský Sokolec/Ipolyszakállos, Horné Turovce/Felsőtúr, Nenince/Lukanénye (the Ipel//Ipoly region Palóc dialect group), Šíd/Síd, Nová Bašta/Újbást (Central Palóc dialect group), Cíž/Csíz, Včelince/Méhi (Eastern Palóc dialect group), and Veľká Ida/Nagyida (Hornád/Hernád region Palóc dialect group). Volume 3 documents the Ung subregion and the Upper Bodrogköz subregion of the Northeastern dialect region, through the following sites (from east to west): Velké Slemence/Nagyszelmenc, Ptrukša/Szirénfalva, Čičarovce/Csicser, Boľ/Boly, Zatín/Zétény, and Oborín/Abara. The regional dialect texts were collected by the faculty and former and present-day students of the Nitra/Nyitra university, while the phonetic transcription of the texts and their alignment with the audio files was carried out by myself.

\section{DIGITAL DIALECTOLOGY IN EDUCATION}

With the present-day dialect texts being used as illustrations of the main dialects of Slovakia Hungarian, the three volumes of the Slovakia Hungarian regional dialect audiobooks provide an excellent opportunity for making teaching about dialects more diverse, interesting, and interactive. The possible educational uses of the audiobooks were described in an earlier paper (Presinszky, 2018).

The points of connection between regional dialects and mother tongue education have been dealt with in a number of publications in recent years. A comprehensive treatment of the topic, including international insights, is provided in Kiss (2001), whereas Kontra (2003) discusses Hungarian and international examples illustrating the interconnectedness of language and school, of regional dialects and mother tongue education. It is necessary to discuss the regional

${ }^{1}$ https://www.fss.ukf.sk/hu/tudomanyos-tevekenyseg/szlovakiai-magyar-nyelvjarasi-hangoskoenyv. 
characteristics of present-day spoken Hungarian in the school, since most students - actually, in minority contexts the overwhelming majority of the students - speak a regional dialect as their vernacular; without a discussion of this fact, it is very difficult to fulfill the main goal of mother tongue education, i.e. the teaching of the standard. It is imperative that a valid picture of dialects is given in the classroom, since myths surrounding them are very widespread. Some of these myths are, for instance, that the number of dialect speakers is low; Hungarians outside Hungary speak only regional dialects; regional dialects are debased versions of the standard; people who use regional dialects have low intelligence; regional dialects are sustained and used by peasants; and regional dialects preserve a "pure" state of the language. In addition to destroying such myths, on a theoretical plane the implementation of additive mother tongue education would be the most important goal to achieve. Under such an approach, the vernaculars of the students and their relationship with them would be left intact, the students' repertoires would widen, and students would be able to use both the dialect and the standard, depending on what a given situation calls for, since choosing one or the other is completely appropriate, if fitting the situation at hand. Through using additive teaching strategies teachers do not weaken but strengthen their students' self-esteem. The standard can be taught successfully through a contrastive method based on the students' own dialect, according to Menyhárt et al. (2009, pp. 13-18), who devote a whole chapter to teaching about dialects at the university level. The authors believe that there are many theoretical issues that need to be clarified about the topic, especially regarding the minority language context. Devising practical methodological approaches would be especially pressing. The volume provides some specific contrastive tasks that can be used in teaching grammar at the primary and secondary school levels.

The above discussed audiobooks can also provide assistance to teaching, since they would allow students to browse through the texts and the aligned audio files with their mobile phones or tablets in class as well as to copy and edit parts of them. The audiobooks are used in tasks (see Presinszky, 2018) which point out dialect phenomena using the students' knowledge of grammar (phonology, morphology, and syntax) in the spirit of additive methods of teaching. They also point out differences between spoken and written language, as well as use reading tasks that illustrate the diverse content of texts, which can also be used as texts popularizing ethnography, cultural studies, and local history. These tasks have also been used successfully in my own university seminars on regional dialects at the Nitra/Nyitra university.

\section{CONCLUSION}

Recent research into Slovakia Hungarian dialects has utilized methods of digital dialectology and has produced unique outputs, assisting scholarly research and allowing for a wide distribution of research results. Research into dialects can be aided by digital methods at every stage, from the planning of the research and carrying out the data collection, transcription, and analysis, to the presentation of the research results. A great advantage of digital recordings is that they can be listened to an infinite number of times without getting worn or damaged, thereby also allowing for more precise transcription. Interactive output provides a possibility to learn about dialects interactively, which might attract more attention from people outside the linguistic profession. It is also greatly important that Slovakia Hungarian regional dialect research is carried out more or less in parallel with similar research in Hungary and other countries neighboring it, e.g. in 
Romania (Gál and Hochbauer, 2011), which, in turn, allows for a comparative Carpathian Basin synchronic analysis of dialect phenomena. The Bihalbocs dialect software can integrate digitized language data and serve as the basis for a unified Hungarian dialect corpus.

\section{ACKNOWLEDGEMENTS}

Present paper has been carried out as part of the project VEGA 1/0170/18 "Hungarian Minority Language Variety in Slovakia“.

\section{REFERENCES}

Balogh, L. and Kiss, G. (1992). A magyar nyelvjárások atlaszának számítógépes feldolgozása [The digitization of the Hungarian dialect atlas]. In: Kontra, M. (Ed.), Társadalmi és területi változatok a magyar nyelvben [Social and regional varieties of the Hungarian language]. Magyar Tudományos Akadémia Nyelvtudományi Intézete, Budapest, pp. 5-17.

Bodó, C. and Vargha, F.S. (2008). Régi nyelvatlaszok - új módszerek: Nyelvtechnológiai eljárások a nyelvföldrajzban [Old linguistic atlases and new methods: Language technological methods in dialect geography]. Magyar Nyelv, 104(3): 335-351.

Cs. Nagy, L. (2011). Medvesalja magyar nyelvjárási atlasza [The Hungarian dialect atlas of Podmedvedie/ Medvesalja]. Luminosus n.o. Kiadó, Nagykapos.

Deme, L. and Imre, S. (Eds.) (1968-1977). A magyar nyelvjarasok atlasza. 1-6 [Hungarian dialect atlas, vols. 1-6]. Akademiai Kiado, Budapest.

Gál, N. and Hochbauer, M. (2011). Vöő István dialektológiai kutatásainak digitális feldolgozási lehetőségeiről [On the possibilities of digitizing István Vöö's studies on dialectology]. In: János, B.M. and Vargha, F.S (Eds.), Hangok - helyek: Tanulmányok dialektológiai adattárak és helynévtárak számitógépes feldolgozásáról [Sounds and places: Studies on the digitization of dialectological and place name databases]. ELTE Magyar Nyelvtudományi és Finnugor Intézet, Budapest, pp. 87-94.

Gósy, M. (2004). Fonetika, a beszéd tudománya [Phonetics, the science of speech]. Budapest: Osiris Kiadó.

Juhász, D. (2014). A dialektológia számítógépes támogatása: Rövid hazai körkép [Digital support for dialectology: A brief overview of Hungarian resources]. Magyar Nyelvjárások, 52: 57-64.

Kiss, J. (Ed.) (2001). Magyar dialektológia [Hungarian dialectology]. Budapest: Osiris Kiadó.

Kontra, M. (Ed.) (2003). Nyelv és társadalom a rendszerváltáskori Magyarországon [Language and society in Hungary at the time of regime change]. Osiris Kiadó, Budapest.

Menyhárt, J. (2012). Kis kácsa fürdik: Egy csallóközi nyelvjárási jelenség vizsgálata [A little duck is swimming: Investigating a regional dialect feature of the Žitný ostrov/Csallóköz dialect]. In: Simon, S. and Török, T. (Eds.), A tudomány vonzásában: Köszöntö kötet a 70 éves Vörös Ottó tiszteletére [Attracted to scholarship: Festschrift for Ottó Vörös on the occasion of his 70th birthday]. Selye János Egyetem, Komárom, pp. 131-144.

Menyhárt, J. and Presinszky, K. (2013). A szórványos ö-zés vizsgálata a Csallóközben generációk és iskolázottság szerint [Investigating dialect islands of ö pronunciation in the Žitný ostrov/Csallóköz dialect by generation and education]. In: Kontra, M., Németh, M., and Balázs, S. (Eds.), Elmélet és 
empíria a szociolingvisztikában: Válogatás a 17. Élönyelvi Konferencia - Szeged, 2012. augusztus 30. szeptember 1. - elóadásaiból [Theory and empirical methods in sociolinguistics: Selected papers from the 17th Conference of Hungarian Sociolinguistics, August 30-September 1, 2012, in Szeged]. Gondolat Kiadó, Budapest, pp. 444-458.

Menyhárt, J., Presinszky, K., and Sándor, A. (2009). Szlovákiai magyar nyelvjárások [Slovakia Hungarian regional dialects]. Konstantin Filozófus Egyetem, Nyitra.

Presinszky, K. (2012). A csallóközi kàlács: Az á előtti asszociatív illabiális a -zás nyelvföldrajzi jellemzői a Csallóközben [Language geographic characteristics of the use of assimilative $\dot{a}$ before $a ́$ in the Žitný ostrov/Csallóköz region]. In: Simon, S. and Török, T. (Eds.), A tudomány vonzásában: Köszöntö kötet a 70 éves Vörös Ottó tiszteletére [Attracted to scholarship: Festschrift for Ottó Vörös on the occasion of his 70th birthday]. Selye János Egyetem, Komárom, pp. 111-129.

Presinszky, K. (2016a). A magánhangzó-rövidülés vizsgálata a Csallóközben [Vowel shortening in the Žitný ostrov/Csallóköz region]. In: Kozmács, I. and Vančo, I. (Eds.), Sztenderd - nem sztenderd: Variációk egy nyelv változataira. Válogatás a 18. Élónyelvi Konferencia (Nyitra, 2014. szeptember 18-20.) elóadásaiból [Standard vs. nonstands: Variation on variations in a language. Selected papers from the 18th Conference of Hungarian Sociolinguistics, September 18-20, 2014, Nitra/Nyitra]. Antológia Kiadó, Lakitelek, pp. 189-199.

Presinszky, K. (2016b). Az á előtti illabiális $\dot{a}$-zás a Csallóközben [Using unrounded $\dot{a}$ before $a$ in the Žitný ostrov/Csallóköz region]. Magyar Nyelv, 112(2): 218-227.

Presinszky, K. (2018). Nyelvjárási hangoskönyv a nyelvtanórán [The use of Hungarian dialect recordings in teaching Hungarian]. Katedra: szlovákiai magyar pedagógusok és szülők lapja, 25(9): 12-13.

Sándor, A. (2004). A Nyitra-vidéki magyar nyelvjárások atlasza [A dialect atlas of Hungarian regional dialects of the Nitra/Nyitra region]. Kalligram Könyvkiadó, Pozsony.

Vargha, F.S. (2007). A magyar nyelvjárási hangoskönyv és elemzési lehetőségei [Recordings of Hungarian regional dialects and possibilities of researching them]. In: Zelliger, E. (Ed.), Nyelv, területiség, társadalom: A 14. Élónyelvi Konferencia (Bük, 2006. október 9-11.) elóadásai [Language, geography, and society: Papers from the 14th Conference of Hungarian Sociolinguistics, October 9-11, 2006, Bük]. Magyar Nyelvtudományi Társaság Kiadványai, Budapest, pp. 429-443.

Vargha, F.S. (2011). Beszélő térképlapok A magyar nyelvjárások atlaszából [Maps speak: The Hungarian dialect atlas]. In: János, B.M. and Vargha, F.S. (Eds.), Hangok - helyek: Tanulmányok dialektológiai adattárak és helynévtárak számitógépes feldolgozásáról [Sounds and places: Studies on the digitization of dialectological and place name databases]. ELTE Magyar Nyelvtudományi és Finnugor Intézet, Budapest, pp. 151-169.

Vargha, F.S. (2017). A nyelvi hasonlóság földrajzi mintázatai: Magyar nyelvjárások dialektometriai elemzése [Geographic patterns of linguistic similarity: A dialectometric analysis of Hungarian dialects]. Magyar Nyelvtudományi Társaság, Budapest.

Vékás, D. (2007). Számítógépes dialektológia [Digital dialectology]. In: Guttmann, M. and Molnár, Z. (Eds.), V. Dialektológiai Szimpozion [5th Dialectology Symposion]. Berzsenyi Dániel Főiskola Magyar Nyelvészeti Tanszék, Szombathely, pp. 289-293. 